Syntax Literate : Jurnal Ilmiah Indonesia p-ISSN: 2541-0849 e-ISSN: 2548-1398

Vol. 5, No. 6, Juni 2020

\title{
PENGGUNAAN MODEL CONCEPT SENTENCE TERHADAP KETERAMPILAN MENULIS KARANGAN NARASI SISWA KELAS V SEKOLAH DASAR SE-KOTA MAKASSAR
}

\section{Musmita dan Erwin Akib}

Universitas Muhammadiyah Makassar

Email: musmita07@gmail.com dan Erwin@unismuh@ac.id

\section{Abstract}

This study aims to find out the description of writing skills written by fifth grade elementary school students in Makassar City before and after the application of the Concept Sentence learning model in Indonesian subjects and the effect of using the Concept Sentence learning model in Indonesian subjects on writing skills written by fifth grade school students Makassar City Base. This type of research is a quantitative study that is Quasi Experiment with pre-test, post-test control group design. thus the results of the study using the concept sentence learning model on the skills of writing essays class $V$ in Makassar City the results were positive, the results of learning to write essays by using the concept sentence learning model showed better learning outcomes than before being applied. This proves that there is an influence of the use of the concept sentence learning model on the writing skills of the fifth grade students of Makassar City Elementary School.

\section{Keywords: Concept Sentence, Authorship, Writing Skills}

\begin{abstract}
Abstrak
Penelitian ini bertujuan Untuk mengetahui gambaran keterampilan menulis karangan siswa kelas V Sekolah Dasar Se Kota Makassar sebelum dan sesudah penerapan model pembelajaran Concept Sentence pada mata pelajaran bahasa Indonesia dan pengaruh penggunaan model pembelajaran Concept Sentence pada mata pelajaran bahasa Indonesia terhadap keterampilan menulis karangan siswa kelas V Sekolah Dasar Se-Kota Makassar. Jenis penelitian ini adalah penelitian kuantitatif yang sifatnya Quasi Experiment dengan pre-test, post-test control group desain. dengan demikian hasil penelitian penggunaan model pembelajaran concept sentence terhadap keterampilan menulis karangan kelas V Se-Kota Makassar hasilnya positif, hasil belajar menulis karangan dengan menggunakan model pembelajaran concept sentence menunjukkkan hasil belajar yang lebih baik dari pada sebelum diterapkan. Hal ini membuktikan bahwa ada pengaruh penggunaan model pembelajaran concept sentence terhadap keterampilan menulis karangan siswa kelas V Sekolah Dasar Se-Kota Makassar.
\end{abstract}

Kata kunci: Concept Sentence, Karangan, Keterampilan Menulis. 


\section{Pendahuluan}

Perpaduan kemajuan teknologi komputer dan teknologi komunikasi telah menciptakan berbagai kosakata/istilah baru di bidang tertentu. Kosakata atau istilah yang dapat digunakan dalam bahasa asing dapat diserap ke dalam Bahasa Indonesia berdasarkan penggunaan bahasa tersebut. Pengalihan kosakata/istilah bidang ilmu itu ke dalam bahasa Indonesia, kalau tidak secepatnya dilakukan, akan menghadapi kendala. Tidak demikian halnya dengan kata/istilah yang baru masuk dalam kehidupan masyarakat langsung dialihkan ke dalam bahasa Indonesia dan diperkenalkan kepada masyarkat pengguna bahasa Indonesia (Erlinawati, 2020).

Keterampilan berbahasa Indonesia dalam kurikulum di sekolah mencakup empat aspek, yaitu: (1) keterampilan menyimak/mendengarkan, (2) keterampilan berbicara, (3) keterampilan membaca, dan (4) keterampilan menulis. Badan Standar Nasional Pendidian (BSNP) (Susanto, 2013), standar isi bahasa Indonesia adalah Pembelajaran bahasa Indonesia diarahkan untuk meningkatkan kemampuan peserta didik untuk berkomunikasi dalam bahasa Indonesia dengan baik dan benar, baik secara lisan maupun tulis, serta menumbuhkan apresisasi terhadap hasil karya sastra manusia Indonesia.

Salah satu aktivitas komunikasi itu adalah menulis. Hal ini juga dijelaskan pada al-qur'an surah al-'Alaq ayat 4 :

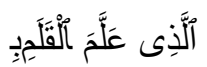

Terjemahnnya :yang mengajar (manusia) dengan pena.(Departemen Agama RI).

Menurut Dalman (2016:3) "menulis merupakan salah satu kegiatan komunikasi berupa penyampaian pesan (informasi) secara tertulis kepada pihak lain dengan menggunakan bahasa tulis sebagai alat atau medianya.

Pada kenyataan yang dijumpai di lapangan adalah tidak semua siswa memiliki keterampilan menulis karangan dengan baik. Masalah yang tampak sehubungan pembelajaran bahasa Indonesia dalam karangan menunjukkan bahwa menulis karangan siswa masih rendah dan kurang terarah pada siswa kelas V tingkat Kecamatan Tamalate Kota Makassar. Hal ini disebabkan oleh adanya beberapa faktor yaitu : 1) siswa saat pembelajaran menulis karangan terlihat kurang terlatih dan tertarik mengikuti pembelajaran menulis pada pelajaran bahasa Indonesia. 2) hasil tulisan atau jawaban siswa belum baik karena kurangnya pemahaman materi, dan 3) siswa belum dapat menuangkan ide dan imajinasinya, penggunaan bahasa yang kurang tepat, dan penggunaan huruf kapital yang masih kurang tepat.

Salah satu alternatif model pembelajaran yang memungkinkan dikembangkan yaitu dengan menggunakan metode concept sentence. Menurut (Huda, 2013) 'concept sentence merupakan strategi pembelajaran yang dilakukan dengan memberikan kartukartu yang berisi beberapa kata kunci tersebut disusun menjadi beberapa kalimat dan dikembangkan menjadi paragraf-paragraf'.

Berdasarkan uraian tersebut, maka peneliti bermaksud untuk melakukan penelitian untuk mengatasi masalah yang berjudul Pengaruh Penggunaan Model 
Concept Sentence terhadap Keterampilan Menulis Karangan Siswa Kelas V Sekolah Dasar Se-Kota Makassar.

Adapun rumusan masalah pada penelitian ini adalah (1) Bagaimanakah gambaran keterampilan menulis karangan narasi siswa kelas V Sekolah Dasar Sekolah Dasar Se-Kota Makassar sebelum dan sesudah penerapan model pembelajaran Concept Sentence pada mata pelajaran bahasa Indonesia? (2) Apakah ada pengaruh penggunaan model pembelajaran Concept Sentence pada mata pelajaran bahasa Indonesia terhadap keterampilan menulis karangan narasi siswa kelas V Sekolah Dasar Se-Kota Makassar?

Berdasarkan rumusan masalah maka tujuan yang ingin dicapai dalam penelitian ini yaitu (1) Untuk mengetahui gambaran keterampilan menulis karangan siswa kelas V Sekolah Dasar Se-Kota Makassar sebelum dan sesudah penerapan model pembelajaran Concept Sentence pada mata pelajaran bahasa Indonesia. (2) Untuk mengetahui pengaruh penggunaan model pembelajaran Concept Sentence pada mata pelajaran bahasa Indonesia terhadap keterampilan menulis karangan siswa kelas V Sekolah Dasar Se-Kota Makassar.

Dalam setiap keterampilan dipunyai hubungan yang sangat erat dengan tiga keterampilan lainnya. Karena dalam memperoleh keterampilan berbahasa, biasa kita melalui suatu hubungan yaitu awal pada masa kecil kita, belajar menyimak bahasa kemudian berbicara, setealah itu kita belajar membaca dan menulis. Keempat keterampilan menyimak, berbicara, membaca, dan menulis adalah suatu kesatuan. (Henry Guntur Tarigan, 2008).

Menurut Dalman (2016:3), menulis merupakan suatu kegiatan komunikasi berupa penyampaian pesan (informasi) secara tertulis kepada pihak lain dengan menggunakan bahasa tulis sebagai alat atau medianya. Selain itu tujuan menulis menurut (G. H. Tarigan, 2013) adalah Assignment purpose (tujuan penugasan), Altruistic purpose (tujuan alturistik), Persuasive purpose (tujuan persuasif), Informational purpose (tujuan informasional, tujuan penerangan), Self-expressive purpose (tujuan pernyataan diri), Creative purpose (tujuan kreatif), dan Problem-solving purpose (tujuan pemecahan masalah).

Kemampuan menulis. Kemampuan menulis adalah keterampilan seseorang menggunakan bahasa tulis sebagai alat, baik wadah maupun media untuk memaparkan isi jiwanya, penghayatan, dan pengalamannya secara teratur. Menurut (Munirah, Bahri, \& Fatmawati, 2019) bahwa tes kemampuan menulis dapat dilakukan dengan dua metode langsung atau tidak langsung. Dalam metode langsung peserta tes (siswa) diminta membuat tulisan (karangan) berdasarkan topik-topik tulisan tertentu.

Adapun indikator keterampilan menulis yaitu: 1) Isi gagasan yang dikemukakan, 2) Organisasi isi, 3) Kosakata, 4) Ejaan dan Tanda Baca (Munirah et al., 2019) Karangan. Pengertian karangan merupakan suatu proses menyusun, mencatat, dan mengkomunikasikan makna dalam tataran ganda, bersifat interaktif dan diarahkan untuk mencapai tujuan tertentu dengan menggunakan suatu sistem tanda konvensional yang dapat dilihat. Karangan terdiri dari paragraf-paragraf yang mencerminkan kesatuan makna yang utuh. 
Ada beberapa jenis karangan seperti narasi (kisah, naratif), ekspoisisi, deskripsi (pemerian, deskriptif), dan argumentasi.

Model Concept sentence. Saat ini telah banyak model pembelajaran yang digunakan unuk mengaktifkan murid dalam pembelajaran dan salah satunya adalah model pembelajaran concept sentence. Menurut (Huda, 2013) Concept sentence merupakan salah satu model pembelajaran konsep dengan menggunakan kata kunci.

Adapun beberapa kelebihan dari penggunaan teknik concept sentence dalam proses pembelajaran. Menurut (Huda, 2013) adalah (1) meningkatkan semangat belajar peserta didik, (2) membantu terciptanya suasana belajar yang kondusif, (3) memunculkan kegembiraan dalam belajar,(4) mendorong dan mengembangkan proses berpikir kreatif,(5) mendorong peserta didik untuk memandang sesuatu dalam pandangan yang berbeda, (6) memunculkan kesadaran untuk berubah menjadi lebih baik, (7) memperkuat kesadaran diri, (8) lebih memahami kata kunci dari materi pokok pembelajaran, dan (9) siswa yang lebih pandai mengajari temannya yang kurang pandai.

\section{Metode Penelitian}

Penelitian ini adalah penelitian kuantitatif yang sifatnya Quasi Eksperiment. Dimana Desain penelitian Control Group Design dimana kelompok eksperimen dan kontrol dibandingkan dua kelompok yang ada diberi pre-test, kemudian diberikan perlakuan, terahkir diberikan post test. Lokasi penelitian ini dilakukan di sekolah dasar kelas V se-Kota Makassar. Adapun subjek penelitian ini adalah di SDN Kaccia, SDI Pingtiku I, SDN Bertingkat Labuang Baji, dan SDN Sangir Kota Makassar dengan jumlah seluruh siswa adalah 100 siswa. Teknik pengambilan sampel yang di-gunakan adalah Cluster Random Sampling. Adapun sampel yang digunakan adalah siswa kelas V SDN Kaccia 25 siswa, SDI Pingtiku I 25 siswa, SDN Bertingkat Labuang Baji 25 siswa, dan SDN Sangir 25 siswa.

Teknik pengumpulan data serta instrument yang digunakan adalah teknik tes. Dimana Teknik pengumpulan data yang digunakan dalam penelitian ini adalah tes awal dan tes akhir. Tes awal dilakukan sebelum treatment, pretest dilakukan untuk mengetahui kemampuan yang dimiliki oleh siswa sebelum diterapkannya metode concept sentence. Sedangkan tes akhir adalah post-test untuk mengetahui pengaruh penggunaan metode concept sentence. Akan tetapi sebelum instrumen tes diujikan, perlu diadakan uji validitas. Validitas digunakan untuk me-ngetahui ketetapan alat penilaian terhadap konsep yang dinilai sehingga betul-betul menilai apa yang seharusnya dinilai.

Pada teknik analisis data, digunakan tiga macam uji yang terdiri dari uji normalitas, uji homogenitas, dan uji hipotesis. Uji normalitas digunakan untuk mengetahui suatu sampel berasal dari populasi yang berdistribusi normal atau tidak. Adapun tujuan dari uji homogenitas ini adalah untuk mengetahui apakah sampel penelitian ini berasal dari populasi yang homogen atau tidak. Uji hipotesis digunakan untuk mengetahui pengaruh dari model Concept Sentence terhadap keterampilan 
menulis karangan pada siswa kelas V Sekolah Dasar se-Kota Makassar. Analisis data yang digunakan adalah uji $t$.

\section{Hasil dan Pembahasan}

\section{A. Hasil}

Pada hasil penelitian tentang pengaruh model concept sentence dalam keterampilan menulis karangan siswa kelas V sekolah dasar Se-Kota Makassar. Proses penelitian ini direncanakan yakni peneliti memberikan pretest pada kelas eksperimen dan kelas kontrol kemudian memberikan perlakukan pada kelas eksperimen setelah itu diberikan posttest pada kelas eksperimen dan kelas kontrol.

\section{Tabel 1}

Analisis Data Tes Awal (Pretest) Kelas Eksperimen dan Kelas Kontrol Pretast Kelas Eksperimen dan Kelas Kontrol

Data Pretes Pretes Kontrol

Eksperimen

\begin{tabular}{ccc}
\hline Mean & 64.80 & 62.80 \\
\hline Median & 65.00 & 60.00 \\
\hline Mode & 65 & 60 \\
\hline Std. Deviation & 9.581 & 9.100 \\
\hline Minimum & 45 & 45 \\
\hline Maximum & 85 & 85 \\
\hline
\end{tabular}

Tabel di atas menunjukkan bahwa nilai rata-rata hasil tes awal (Pretest) siswa pada kelas eksperimen dan kelas kontrol tidak jauh berbeda yaitu SDN Kaccia, SD Negeri Pongtiku I (Kelas eksperimen) yaitu 65,00 dan kelas kontrol SDI Bertingkat Labuang Baji, SD Negeri Sangir (kelas kontrol) yaitu 60,00. Dimana Nilai siswa kelas eksperimen pada SDN Kaccia yang memperoleh 50 sebanyak 3 siswa, nilai 55 sebanyak 3 siswa, nilai 60 sebanyak 5 siswa, nilai 65 sebanyak 8 siswa, nilai 70 sebanyak 3 siswa, nilai 75 sebanyak 1 siswa, nilai 80 sebanyak 1 siswa, dan nilai 85 sebanyak 1 siswa. Sedangkan nilai siswa pada SDN Pongtiku I yang memperoleh nilai 45 sebanyak 1, nilai 50 sebanyak 1 siswa, nilai 55 sebanyak 4 siswa, nilai 60 sebanyak 2 siswa, nilai 65 sebanyak 5 siswa, nilai 70 sebanyak 7 siswa, nilai 75 sebanyak 1 siswa, nilai 80 sebanyak 2 siswa, dan nilai 85 sebanyak 2 siswa. Dan Nilai siswa kelas kontrol pada SD Labuang Baji yang memperoleh nilai 45 sebanyak 1 siswa, nilai 55 sebanyak 4 siswa, nilai 60 sebanyak 9 siswa, nilai 65 sebanyak 5 siswa, nilai 70 sebanyak 4 siswa, nilai 80 sebanyak 1 siswa, dan nilai 85 sebanyak 1 siswa. Sedangkan nilai siswa pada SDN Sangir yang memperoleh nilai 50 sebanyak 6 siswa, nilai 55 sebanyak 2 siswa, nilai 60 sebanyak 4 siswa, nilai 65 sebanyak 6 siswa, nilai 70 sebanyak 3 siswa, nilai 75 sebanyak 2 siswa, nilai 80 sebanyak 1 siswa, dan nilai 85 sebanyak 1 siswa. 
Tabel 2

Analisis Data Tes Akhir (Post-test) Kelas Eksperimen dan Kelas Kontrol

\begin{tabular}{ccc}
\hline & Posttest_Eksperimen & Posttest_Kontrol \\
\hline Mean & 85.60 & 72.90 \\
Median & 85.00 & 70.00 \\
Mode & 85 & 70 \\
Std. Deviation & 7.117 & 7.429 \\
Minimum & 75 & 60 \\
Maximum & 100 & 95 \\
\hline
\end{tabular}

Tabel di atas menunjukkan bahwa nilai rata-rata hasil tes akhir (Post-test) siswa pada kelas eksperimen dan kelas kontrol jauh berbeda yaitu SDN Kaccia, SD Negeri Pongtiku I (kelas eksperimen) yaitu 85,60 dan kelas kontrol SDI Bertingkat Labuang Baji, SD Negeri Sangir (kelas kontrol) yaitu 72,90. Nilai hasil evaluasi akhir seluruh siswa kelas V untuk kelas eksperimen di atas KKM yaitu 75 dan kelas kontrol memperoleh nilai di bawah KKM $(\leq 75)$ yang telah ditetapkan. Berdasarkan hasil evaluasi tersebut dapat ditarik kesimpulan bahwa keterampilan menulis karangan narasi siswa pada kelas eksperimen setelah diterapkan model concept sentence termasuk dalam kriteria sangat baik. Sedangkan pada kelas kontrol setelah diterapkan model concept sentence termasuk dalam kriteria kurang. Berdasarkan data tersebut di atas, kemudian dilakukan uji normalitas dengan hasil uji dinyatakan dalam Tabel 3 berikut:

Tabel 3

Hasil Uji Normalitas Postest Kelas Kontrol dan Kelas Eksperimen Kota Makassar

\begin{tabular}{llc}
\hline & \multicolumn{2}{c}{ Data_Posttest } \\
\hline Normal & Location & 79.25 \\
\cline { 2 - 3 } Distribution & Scale & 9.650 \\
\hline
\end{tabular}

Berdasarkan tabel di atas bahwa hasil uji normalitas pada pretest kelas eksperimen dan kelas kontrol diperoleh data berdistribusi normal dan kemudian dilanjutkan uji homogenitas.

Tabel 4

Hasil Uji Homogenitas Kelas Kontrol dan Kelas Eksperimen Kota Makassar

\begin{tabular}{lcccc}
\hline & $\begin{array}{c}\text { Levene } \\
\text { Statistic }\end{array}$ & df1 & df2 & Sig. \\
\hline Based on Mean & .013 & 1 & 98 & .911 \\
Based on Median & .008 & 1 & 98 & .928 \\
Based on Median and with adjusted df & .008 & 1 & 93.174 & .928 \\
Based on trimmed mean & .004 & 1 & 98 & .948 \\
\hline
\end{tabular}

Test of Homogeneity of Variance 
Berdasarkan tabel di atas diketahui nilai signifikansi (Sig.) based on mean sebesar 0,911>0,05, dari hasil uji homogenitas variansi tersebut, dinyatakan bahwa variansi populasi adalah sama (homogen).

\section{Tabel 5}

\begin{tabular}{cccc} 
& \multicolumn{3}{c}{ Uji $_{\text {hitung }}$ dan $\mathbf{t}_{\text {tabel }}$} \\
\hline Kelompok & $\mathrm{t}_{\text {hitung }}$ & $\mathrm{t}_{\text {tabel }}$ & Keterangan \\
\hline $\begin{array}{l}\text { Eksperimen } \\
\text { dan kontrol }\end{array}$ & 8,729 & $1,66$. & $\mathrm{H}_{0}$ ditolak \\
\hline
\end{tabular}

Berdasarkan tabel di atas diperoleh nilai sig (2-tailed) sebesar 0,000 $<0,05$ maka dapat disimpulkan ada perbedaan ditemukan adanya pengaruh yang signifikan antara hasil pembelajaran dengan menggunakan model concept sentence dengan hasil pembelajaran dengan menggunakan pembelajaran konvensioanal. Karena pada nilai $t$ hitung yang diperoleh adalah 8,729 sedangkan $t_{\text {tabel }}$ yang diperoleh adalah 1,66. Berdasarkan hasil uji hipotesis tersebut dinyatakan bahwa nilai $\mathrm{t}_{\text {hitung }}>$ nilai $\mathrm{t}_{\text {tabel }}(8,729>1,660)$ sehingga dapat ditarik kesimpulan bahwa dalam penelitian ini diterima. Dengan demikian model concept sentence terdapat pengaruh dalam pembelajaran menulis karangan siswa kelas V SD Se-Kota Makassar.

Berdasarkan hasil nilai rata-rata, diperoleh data bahwa nilai rata-rata keterampilan menulis karangan pada kelompok eks-perimen sebanyak 85,60 sedangkan nilai ra-ta-rata keterampilan menulis karangan pada kelompok kontrol sebanyak 72,90. Dengan demikian, dapat disimpulkan bahwa model Concept Sentence mempunyai pengaruh daripada model pembelajaran konvensional pada materi menulis karangan.

\section{B. Pembahasan}

Pada bagian ini diuraikan cara penerapan model concept sentence terhadap keterampilan menulis karangan siswa kelas V Se-Kota Makassar. Berdasarkan hasil analisis deskriptif data tes awal (pretest) dan tes akhir (posttest) keterampilan menulis siswa kelas $\mathrm{V}$ pada kelas eksperimen menggunakan model concept sentence dan kelas kontrol menggunakan model konvensional menunjukkan bahwa nilai siswa yang berada pada kelas eksperimen (SDN Kaccia dan SDI Pongtiku I) dengan menggunakan model concept sentence lebih tinggi. Dimana langkahlangkah pembelajaran model cencept sentence yang diberikan pada kelas eksperimen pada SD Kaccia dan SD Pongtiku I yaitu guru meyampaikan tujuan yang akan dicapai yaitu menulis karangan berdasarkan informasi penting yang telah ditemukan dengan menggunakan bahasa sendiri kemudian guru memberikan apersepsi dan melakukan eksplorasi tentang materi atau tema yang dipelajari seperti siswa diajak menyanyikan lagu Indonesia raya dan memberikan penguatan tentang pentingnya menanamkan semangat kebangsaan, dan guru menjelaskan materi tentang karangan dan teks bacaan, setelah itu siswa membentuk kelompok yang beranggotakan masing-masing 4 siswa dalam satu kelompok secara heterogen, 
kemudian guru memberikan beberapa kata kunci dalam kartu (2-5 kata kunci/kartu) dimana dalam kartu-kartu tersebut terdapat sebuah pertanyaan untuk menggali informasi pada cerita, selanjutnya tiap-tiap kelompok membuat karangan dengan paragraf sederhana yang terdiri atas minimal 4 kalimat kemudian dari hasil diskusi kelompok didiskusikan kembali dan dipandu oleh guru kemudian membuat kesimpulan.

Hal ini ditunjukkan bahwa materi pelajaran yang disampaikan kepada siswa oleh guru tersampaikan dengan baik dan dapat dipahami oleh siswa dengan menggunakan model concept sentence. Pemahaman siswa terhadap materi yang diajarkan dikarenakan oleh penggunaan model concept sentence yang digunakan pada kelas eksperimen (SDN Kaccia dan SDI Pongtiku). Concept sentence merupakan strategi pembelajaran yang dilakukan dengan memberikan kartu-kartu yang berisi beberapa kata kunci tersebut disusun menjadi beberapa kalimat dan dikembangkan menjadi paragraf-paragraf (Huda, 2015:315). Penggunaan model concept sentence pada kelas eksperimen membuat siswa aktif dalam proses pembelajaran dimana siswa bekerja kelompok untuk membuat sebuah karangan dan siswa dapat membuat sebuah karangan dengan mudah dengan menggunakan kata kunci dari kartu-kartu yang telah dibagikan.

Hal ini dapat dilihat dari data tentang menulis karangan siswa kelas V SDI Bertingkat Labuang Baji dan SD Negeri Sangir untuk kelas kontrol pretest diperoleh data yaitu: skor tertinggi 85 dan skor terendah 45, rata-rata (mean) sebesar 62,80, median sebesar 60,00, modus sebesar 60 dan standar deviasi sebesar 9,100 sedangkan data yang diperoleh pada pretest kelas eksperimen yaitu: skor tertinggi 85 dan skor terendah 45, rata-rata (mean) 64,80, median 65,00, modus 65 dan standar deviasi 9.581. Berdasrkan data yang diperoleh dapat disimpulkan bahwa keterampilan menulis siswa kelas V Se-Kota Makassar sebelum diterapakan model pembelajaran concept sentence termaksud dalam kategori sangat kurang dengan melihat pada pedoman keterampilan menulis.

Data keterampilan menulis karangan siswa kelas V Se-Kota Makassar setelah diterapkan model concept sentence untuk posttest kelas kontrol diperoleh data yaitu: skor tertinggi 90 dan skor terendah 60, rata-rata (mean) 72,90, tmedian 70,00 , modus 70 dan standar deviasi 7,429 sedangkan data hasil postest kelas eksperimen diperoleh data yaitu: skor tertinggi 100 dan skor terendah 75, rata-rata (mean) 85,69, median 85,00 modus 85 dan standar deviasi 7,117. Berdasarkan nilai rata-rata pada kelas eksperimen dan kelas kontrol dapat disimpulkan bahwa dengan menerapkan model concept sentence dalam menulis karangan siswa kelas V terdapat pengaruh. Hal itu dapat dibuktikan dari nilai posttest rata-rata siswa kelas kontrol 72,90 sedangkan nilai rata-rata kelas eksperimen posttest 85,60.

Berdasarkan hasil uji hipotesis dengan statistik inferensial (t-test) independent samples test dengan kriteria pengujian, hipotesis alternatif $\left(\mathrm{H}_{1}\right)$ diterima apabila nilai $\mathrm{t}_{\text {hitung }} \geq$ nilai $\mathrm{t}_{\text {tabel. }}$. Sebaliknya, $\mathrm{H}_{0}$ ditolak apabila nilai $\mathrm{t}_{\text {hitung }}$ $<$ nilai $\mathrm{t}$ tabel pada taraf signifikan $0,05 \%$. Hasil uji beda ( $t$-test) data tes menulis 


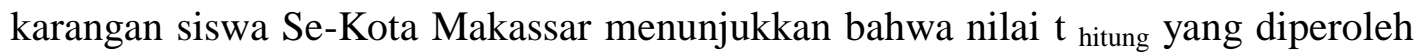
adalah $=8,729$ sedangkan $\mathrm{t}$ tabel dengan taraf signifikasin 0,05 adalah 1,66. Bedasarkan hasil uji hipotesis dengan statistik inferensial (t-test) independent samples test) tersebut, dinyatakan bahwa hipotesis penelitian diterima karena nilai $\mathrm{t}$ hitung $>$ nilai $\mathrm{t}$ tabel $(8,729>1,66)$, sehingga dapat ditarik kesimpulan bahwa hipotesis dalam penelitian ini diterima yaitu model concept sentence berpengaruh dalam pembelajaran keterampilan menulis karangan siswa kelas V Se-Kota Makassar.

\section{Kesimpulan}

Keterampilan menulis karangan narasi siswa kelas V Se-Kota Makassar sebelum diterapkan model concept sentence pada pelajaran bahasa Indonesia adalah termasuk kategori sangat kurang. hal ini dapat dilihat pada nilai rata-rata (mean) siswa kelas eksperimen 64,80 dan nilai rata-rata (mean) kelas kontrol adalah 62,80. Sedangkan setelah diterapkan model concept sentence pada pelajaran bahasa Indonesia mengalami peningkatan hasil belajar yang signifikan. Hal ini dapat dilihat pada kelas eksperimen dikategorikan sangat baik dengan nilai rata-rata siswa yaitu 85,60, dan pada kelas kontrol dikategorikan kurang dengan nilai rata-rata siswa 72,90.

Penerapan model concept sentence terhadap keterampilan menulis karangan siswa kelas V Se-Kota Makassar terdapat pengaruh. Hal ini dapat dilihat dari hasil analisis uji-t independen menunjukkan bahwa perbedaan signifikan dari nilai nilai $t$ hitung yang diperoleh adalah $=8,729$ sedangkan $\mathrm{t}$ tabel dengan taraf signifikasin 0,05 adalah 1,660. Bedasarkan hasil uji hipotesis dengan statistik inferensial (t-test) independent samples test) tersebut, dinyatakan bahwa hipotesis penelitian diterima karena nilai $t_{\text {hitung }}>$ nilai $t_{\text {tabel }}(8,729>1,660$, sehingga dapat ditarik kesimpulan bahwa hipotesis dalam penelitian ini diterima yaitu penggunaan model concept sentence terhadap keterampilan menulis karangan siswa kelas V Se-Kota Makassar berpengaruh signifikan. 


\section{BIBLIOGRAFI}

Erlinawati, Mira. (2020). Implementasi Pembakuan Peristilahan Perkomputeran Dalam Bahasa Indonesia Untuk Mahasiswa SI 18A4 FIKOM Universitas Duta Bangsa Surakarta. Syntax Literate; Jurnal Ilmiah Indonesia, 5(2), 92-99.

Huda, Miftahul. (2013). Model-model pengajaran dan pembelajaran. Yogyakarta: pustaka pelajar.

Munirah, Munirah, Bahri, Aliem, \& Fatmawati, Fatmawati. (2019). Pengaruh Penggunaan Media Gambar Seri Terhadap Keterampilan Menulis Cerita Dongeng Siswa Kelas Iii Sd. Jkpd (Jurnal Kajian Pendidikan Dasar), 4(2), 731-740.

Susanto, Ahmad. (2013). Teori belajar dan pembelajaran di sekolah dasar. Jakarta: Kencana prenada media group.

Tarigan, G. H. (2013). Menulis Sebagai Suatu Keterampilan Berbahasa, Bandung: CV. Angkasa.

Tarigan, Henry Guntur. (2008). Berbicara sebagai suatu ketrampilan berbahasa. Bandung: Angkasa, 16. 